\title{
The Victims Rights \& Conditions Protection On Trafficting Crime Through The Implementation of Restitutions
}

\author{
Sefin Anggi Riyantika*) and Jawade Hafidz**) \\ *) Master of Law Program, Faculty of Law Universitas Islam Sultan Agung email \\ sefin96090219@gmail.com \\ **) Faculty of Law Universitas Islam Sultan Agung
}

\begin{abstract}
This study aims to further analyze the protection of victims of the crime of human trafficking who have not been able to accommodate the rights and losses of victims. The approach method used is sociological juridical. Based on the analysis of the existing findings, it is clear that the implementation of the protection of the rights of victims of human trafficking has not been running effectively due to unclear restitution arrangements, both in terms of magnitude and related to criminal arrangements for replacement of restitution. The Crime of Human trafficking is a crime against humanity that can harm a person both materially and physically and mentally. In addition, it is necessary for victims of human trafficking to obtain protection of their rights, which in this case can be done through restitution. In practice, the amount of restitution is not clearly defined. In addition, the existence of a criminal substitute for compensation, which in this case includes restitution, makes the implementation of restitution difficult for victims of human trafficking. Such conditions clearly contradict the First Precepts, Second Precepts, and Fifth Precepts of Pancasila, as well as the Fourth Paragraph of the Preamble to the 1945 Constitution of the Republic of Indonesia as the purpose of the state, as well as Article 28D paragraph (1) and Article 28G Paragraph (1) and Paragraph (2) of the 1945 Constitution of the Republic of Indonesia as the basic foundation related to the human rights of victims of human trafficking, and as a legal ratio in law in Indonesia.
\end{abstract}

Keywords: Rights Protection; Victims, Human Trafficking, Restitution.

\section{Introduction}

In addition to international instruments, human rights are also regulated in national instruments consisting of:

- the 1945 Constitution of the Republic of Indonesia;

- Act No. 68 of 1958 concerning Ratification of the Convention on Women's Political Rights;

- Law of the Republic of Indonesia Number 7 of 1984 concerning Ratification of the Convention Regarding the Elimination of All Forms of Discrimination Against Women;

- Act No. 39 of 1999 concerning Human Rights;

- Act No. 23 of 2004 concerning the Elimination of Domestic Violence;

- Act No. 11 of 2005 concerning Ratification of the International Covenant on Economic, Social and Cultural Rights;

- Act No. 12 of 2005 concerning Ratification of the International Covenant on Civil and Political Rights; 
- Act No. 21 of 2007 concerning the Eradication of Human Trafficking;

- Presidential Instruction No. 9/2000 on Gender Mainstreaming in National Development;

- Presidential Regulation Number 23 of 2011 concerning the 2011-2014 Human Rights Action Plan;

- Act No. 21 of 2007 concerning Eradication of the Crime of Human trafficking; and

- Government Regulation Number 9 of 2008 concerning Procedures and Mechanisms for Integrated Services for Witnesses and/or Victims of the Crime of Human trafficking.

Although it already has international instruments and national instruments in upholding human rights, however, the cases of criminal acts of human trafficking occurring in this country are actually increasing day by day. Originally there were 177 in 2018 who were victims of human trafficking in this country, ${ }^{1}$

Furthermore, KOMNAS PEREMPUAN CATAHU again noted that in 2020 there were 406,178 cases of violence against women or women, including 153 cases of human trafficking. ${ }^{2}$ This clearly contradicts human values as mandated by the second principle of Pancasila and the fourth paragraph of the Preamble to the Constitution of the Republic of Indonesia. Human trafficking has contributed to the destruction of the future of the nation's future generations. This is because human trafficking can cause trafficking victims to suffer from various diseases and experience extraordinary trauma.

Problems related to the increasing number of human trafficking against women also occur in the city of Semarang. According to the Legal Resource Center for Gender Justice and Human Rights (LRC-KJHAM) in 2019, there have been 10 cases of human trafficking, according to the Legal Resource Center for Gender Justice and Human Rights. LRC-KJHAM stated that the highest number of human trafficking cases occurred in areas with weak economic levels of society. ${ }^{3}$

This dilemmatic situation is further exacerbated by the existence of a criminal justice system paradigm that only starts with revenge against the perpetrators through the provisions of existing criminal sanctions, while the restoration of the rights and conditions of victims of human trafficking has never been considered properly.

\section{Research Methods}

The type of research used in this study is a sociological juridical legal research type. The approach uses sociological juridical, the specification in this writing is analytical descriptive. Methods of collecting data by means of field studies and literature studies. Methods of data analysis using qualitative methods.

\section{Results and Discussion}

\footnotetext{
1 Retno Listyarti in nasional.tempo.co, KPAI: Pelanggaran Hak Anak Di Tahun 2018 Didominasi Tindak Kekerasan, Downloaded on January 12, 2021.

2 Komisi Nasional Perempuan, op, cit.

${ }^{3}$ https://serat.id/2019/07/25/case-kerasan-sexual-di-jateng-masih-tinggi/, On April 21, 2020.
} 


\subsection{Implementation of the Current Law for the Protection of Victims of Human trafficking}

Nowadays, the issue of human rights has become a global issue in addition to democracy and environmental issues, and has even become a demand that really needs serious attention for the state to respect, protect, defend and guarantee the human rights of citizens and residents without discrimination. Act No. 39 of 1999 states that human rights are a set of rights that are inherent in the nature and existence of humans as creatures of God Almighty and are His gifts that must be respected, upheld, and protected by the state, law, government and everyone for the honor and protection of human dignity. 4

The criminal act of human trafficking is a violation of human rights, as stated in Act No. 21 of 2007 concerning the Eradication of the Crime of Human trafficking in considering letter b, that human trafficking, especially women and children, is an act that is contrary to human dignity and violates human rights, so they must be eradicated. Furthermore, letter c states that human trafficking has spread in the form of organized and unorganized crime networks, both international and domestic, so that it becomes a threat to society, the nation and the state, as well as to the norms of life based on respect for human rights. ${ }^{5}$

In line with this, legal protection for the community can be achieved properly if it is carried out with integrated and effective law enforcement. Legal protection or law enforcement is the same as law enforcement against criminal acts of human trafficking or human trafficking. Law enforcement regulated in the laws and regulations of the criminal act of human trafficking in Indonesia is carried out by means of punishment in the form of imprisonment, confinement, fines, and restitution. ${ }^{6}$

Other legal protection is the rehabilitation of victims, both medically, psychologically and socially, repatriation and integration that must be carried out by the state, especially for victims who experience physical, psychological, and social suffering as a result of the crime of human trafficking. This law also stipulates provisions regarding the prevention and handling of victims of the crime of human trafficking as the responsibility of the government, local governments, communities, and families, as well as the establishment of a task force to realize integrated steps in the implementation of prevention and handling of human trafficking.

Increased protection for victims of human trafficking is also implemented by increasing the accessibility of services through the establishment of Integrated Service Centers in public hospitals owned by the central and provincial

\footnotetext{
${ }^{4}$ Mahrus Ali and Syarif Nurhidayat, Penyelesaian Pelanggaran HAM Berat In Court System \& Out Court System, Gramata Publishing, Jakarta, 2011, p. 7.

${ }^{5}$ Sarwadi and Bambang Tri Bawono, Restorative Justice Approach in Diversion System for Settlement of Criminal Cases for Children in Indonesia, Jurnal Daulat Hukum Volume 3 Issue 4, December 2020, p. 377-400.

${ }^{6}$ Ibnu Suka, Gunarto, and Umar Ma'ruf, Peran Dan Tanggung Jawab Polri Sebagai Penegak Hukum Dalam Melaksanaan Restorative Justice Untuk Keadilan Dan Kemanfaatan Masyarakat, Jurnal Hukum Khaira Ummah Vol. 13. No. 1 March 2018, p. 115-116.
} 
governments and districts/cities as well as central police hospitals and Bhayangkara hospitals in the regions. Special police service rooms managed by female police officers have been added to the number which now amounts to 226 units in 26 regional (provincial) police forces and will continue to be expanded to other regional police and resort police (districts/municipalities) throughout Indonesia. In addition, more and more non-governmental organizations and community organizations are establishing women's crisis centers, drop-in centers, or shelters, now there are 23 units spread across 15 provinces. Besides that,

\subsection{Juridical Analysis of the Current Protection of Victims of Human trafficking}

In its development, the protection of victims of trafficking in victims has not been able to realize justice. This can be seen in the regulation of restitution in Act No. 21 of 2007 concerning the Eradication of the Crime of Human Trafficking. Regarding restitution in Act No. 21 of 2007 concerning Eradication of the Crime of Human trafficking, it is regulated in Articles 48 to 50.

Article 48

(1) Every victim of the crime of human trafficking or their heirs has the right to receive restitution.

(2) The restitution as referred to in paragraph (1) is in the form of compensation for:

a. loss of wealth or income;

b. suffering;

c. costs for medical and/or psychological treatment measures; and/or

d. other losses suffered by the victim as a result of human trafficking.

(3) The restitution is given and included at the same time in the court's decision regarding the criminal act of human trafficking.

(4) The provision of restitution as referred to in paragraph (1) shall be carried out since the decision of the first instance court is imposed.

(5) The restitution as referred to in paragraph (4) may be deposited in advance at the court where the case was decided.

(6) Restitution is granted within 14 (fourteen) days as of the notification of the decision which has obtained permanent legal force.

(7) In the event that the perpetrator is acquitted by the court of appeal or cassation, the judge shall order in his decision that the restitution money deposited be returned to the person concerned.

Article 49

(1) The implementation of the granting of restitution is reported to the chairman of the court who decided the case, accompanied by evidence of the implementation of the granting of the restitution.

(2) After the chairman of the court receives the evidence as referred to in paragraph (1), the chairman of the court announces the implementation on the notice board of the court concerned. 
(3) A copy of the proof of implementation of the provision of restitution as referred to in paragraph (1) shall be submitted by the court to the victim or his heirs.

\section{Article 50}

(1) In the event that the provision of restitution to the victim is not fulfilled beyond the time limit as referred to in Article 48 paragraph (6), the victim or his heirs shall notify the court of this matter.

(2) The court as referred to in paragraph (1) shall issue a written warning letter to the giver of restitution, to immediately fulfill the obligation to provide restitution to the victim or his/her heirs.

(3) In the event that the warning letter as referred to in paragraph (2) is not executed within 14 (fourteen) days, the court orders the public prosecutor to confiscate the assets of the convict and auction the assets for restitution.

(4) If the perpetrator is unable to pay the restitution, the perpetrator is subject to a maximum imprisonment of 1 (one) year.

Based on the explanation above, it can be seen that in its development the implementation of restitution ${ }^{7}$ become an alternative in an effort to protect and restore the rights of victims who have been injured as a result of the criminal act of Human trafficking. Regarding restitution in its development, it has been clearly regulated in the United Nations Declaration on the Prosecution and Assistance of Crime Victims in item 4 part 1 of the General Principles. ${ }^{8}$

Meanwhile, regarding the regulation of restitution in national legal regulations, it is clearly regulated in Act No. 31 of 2014. In Article 1 number 11 of Act No. 31 of 2014 it is stated that "restitution is compensation given to victims or their families by perpetrators or other parties". Furthermore, Article 7A number 1 of Act No. 31 of 2014 states that:

Victims of criminal acts are entitled to restitution in the form of:

- compensation for loss of property or income;

- compensation for losses caused by suffering directly related as a result of a criminal act; and/or

- reimbursement of medical and/or psychological treatment costs.

Furthermore, Article 3 of the Government Regulation of the Republic of Indonesia Number 43 of 2017 concerning the Implementation of Restitution for

\footnotetext{
${ }^{7}$ Restitution is the restoration of the rights of the victim from the existence of a criminal act in the community. Galeway stated that the purpose of restitution is to recover the losses suffered by the victim as a result of a criminal act, namely by providing appropriate sanctions to the convict and preventing retaliation against the victim. In Indonesia, the restitution system adopted is a procedural rights approach, this is clearly seen in Act No. 31 of 2016 and Government Regulation No. 44 of 2008. The weakness of this restitution system is that the juridical rights of victims are difficult to determine due to non-compliance. clear separation between the victim's personal interests and the public interest, and the next weakness is that the restitution system adopted in Indonesia tends to be easy to abuse. See: Ahmad Sofyan, Pemberian Restitusi Kepadan Korban Tindak Pidana Dalam Sistem Peradilan Pidana Indonesia, Accessed Through businesslaw.binus.ac.id, On 12 May 2021.

${ }^{8}$ Romli Atmasasmita, Penulisan Karya Ilmiah Tentang Masalah Santunan Terhadap Korban Tindak Pidana, Badan Pembinaan Hukum Nasional, Departemen Kehakiman, Jakarta 1992, p. 4.
} 
Children Who Become Victims of Crime states that:

Restitution for children who are victims of criminal acts in the form of:

- compensation for loss of property;

- compensation for suffering as a result of not being criminal; and/or

- reimbursement of medical and/or psychological treatment costs.

In its development, the implementation of restitution for the recovery of victims of human trafficking has not been effective, this is because Article 7 of the Government Regulation of the Republic of Indonesia Number 43 of 2017 still contains administrative requirements that still make it difficult for victims, so that the competent authorities should be able to facilitate the fulfillment of administrative requirements as regulated in Article 7 Government Regulation of the Republic of Indonesia Number 43 of 2017. In addition, the perpetrators of criminal acts are reluctant to pay restitution on the grounds of economic incapacity, it becomes even more unfair because the inability of the perpetrator to pay restitution is only replaced with a subsidiary punishment in the form of imprisonment for 2 to 3 months. Meanwhile, according to Act No. 21 Number 2007.9 In addition, the time for receiving restitution by child victims of human trafficking is also quite long considering the long judicial process, not to mention the perpetrators who are in detention or subject to the death penalty which can then be an excuse for not doing restitution. ${ }^{10}$

Then in 2018 the government issued Government Regulation Number 7 of 2018 concerning the Provision of Compensation, Restitution, and Assistance to Witnesses and Victims. However, in its development the implementation of compensation as another alternative to restitution is also not easy, this is because there is no institution appointed in the Government Regulation to interpret the amount of loss suffered by the victim, besides that it has not been clearly regulated which state institution has the authority to distribute compensation from the human trafficking, especially women. ${ }^{11}$ In addition, the administrative requirements for submitting a request for compensation by the victim are so complicated that it will be a problem for the victim. In the existing explanation, it is clear that the legal umbrella regarding the restoration of the rights and conditions of victims of human trafficking is not yet clear in terms of its implementation, while regarding the restoration of conditions and rights of victims of the crime of human trafficking, it is specifically regulated for child victims as stated in Article 3 of the Government Regulation of the Republic of Indonesia. Number 43 of 2017 concerning the Implementation of Restitution for Victims of the Crime of Human trafficking. This situation is getting worse with the absence of regional formulations related to the restoration of the rights and conditions of victims both materially and immaterially, this clearly also has an impact on the lack of

\footnotetext{
${ }^{9}$ Ragil Tri Wibowo and Akhmad Khisni, Restorative Justice in Application for Crime Investigation on Property, Jurnal Daulat Hukum Volume 1 No. 2 June 2018, p. 555-556.

${ }^{10} \mathrm{C}$. Kamea and Herlien, Penegakan Hukum Pidana Terhadap Kejahatan Perdagangan Orang Menurut Undang-Undang Nomor 21 Tahun 2007, Lex Crimen, V, No. 2, 2016, p. 126-32.

${ }^{11}$ Roswati Dewi, Sri Endah Wahyuningsih, and Umar Ma'ruf, Law Enforcement Of Giving Restitution For Victims Of Trafficking In The State Court Of Central Jakarta, Jurnal Daulat Hukum Volume 2 Issue 4, December 2019, p. 537.
} 
effectiveness in eradicating criminal acts of people in various regions. In addition, most judicial decisions only focus on elements in the law relating to the criminal act of human trafficking, not specifically on the law on eradicating the crime of human trafficking. One of these can be seen in the criminal case of human trafficking in the city of Semarang with the case number49/Pid.Sus/2018/PN SMg. In case No. 49/Pid.Sus/2018/PN SMG, the judge decided that the defendant was acquitted of all lawsuits because the judge only saw that the defendant's actions did not sufficiently meet the legal elements.

Article 103 letter E of Act No. 39 of 2004 concerning the Placement and Protection of Indonesian Migrant Workers Abroad, not based on the elements regulated in Act No. 21 of 2007 concerning the Eradication of the Crime of Human trafficking. This is very unfair considering the consequences of human trafficking can result in physical and psychological losses. Until now, it cannot be said that compensation and restitution can recover psychologically from victims of human trafficking. This is because psychological violence can have a short impact or a long impact. ${ }^{12}$ The short impact is in the form of endangering the safety of the victim, damage to the family structure, and mental and mental disorders. The trauma and experience of being a victim of a criminal act of human trafficking also results in the victim becoming a perpetrator of violence in adulthood if the victim is still a child. This can be seen with symptoms of aggression, phobias, insomnia, low selfesteem, and depression. ${ }^{13}$ This is unfair to victims of the crime of human trafficking.

Such conditions clearly contradict the First Precepts, Second Precepts, and Fifth Precepts of Pancasila, as well as the Fourth Paragraph of the Preamble to the 1945 Constitution of the Republic of Indonesia as the purpose of the state, as well as Article 28D paragraph (1) and Article 28G Paragraph (1) and Paragraph (2) of the 1945 Constitution of the Republic of Indonesia as the basic foundation regarding the human rights of victims of human trafficking, and as a legal ratio in law in Indonesia. ${ }^{14}$

This situation has also violated the basic idea of criminal law development. It is well known that Pancasila and the 1945 Constitution of the Republic of Indonesia have mandated the realization of the life of the nation and the state based on the value of the Godhead of YME as the essence of the religiosity of the Indonesian nation and state, the value of Humanity as a mode of recognition, appreciation and protection of human rights in the life of the Indonesian nation and state. The social values of society that show the life style of the Indonesian

\footnotetext{
${ }^{12}$ Yenny AS, Anita Yuliastini, and Rini Setiawati, The Handling Of Human Trafficking With Mail Order Bride Mode In West Kalimantan, International Journal of Law Recontruction Volume 4, Number 2, September 2020. p. 75-80.

13Maria Advianti, KPAI: Pelaku Kekerasan Terhadap Anak Tiap Tahun Meningkat, Diakses Melalui www. KPAI.go.id, On May 12, 2021. See also: Margaretha, Rahmaniar Nuringtyas, and Rani Rachim, Trauma Masa Kanak Dan Kekerasan Dalam Relasi Intim, Makara Seri Sosial Humaniora, 2013, p. 34.

${ }^{14}$ Agus Takariawan and Sherly Ayuna Putri, Perlindungan Hukum terhadap Korban Human Trafficking dalam Perspektif Hak Asasi Manusia, Jurnal Hukum IUS QUIA IUSTUM NO. 2 VOL. 25 MAY 2018, p. 237-240.
} 
nation and state which is nationalist, democratic, and upholds the value of social justice for all groups of Indonesian society. ${ }^{15}$

This is clearly shown that the criminal application of the crime of human trafficking only relies on the actions and the perpetrators while the victims are excluded. ${ }^{16}$ This is also clearly contrary to the purpose of law according to Islam. In its development. The principle of Maqasid Al-Syariah has explained that the law must be able to protect five things, as for the five things are: ${ }^{17}$ Religion; Intellect; Soul; Property; Descendants.

This has clearly violated the mandate of the teachings of Islam. Islam has taught every human being to always protect fellow human beings as brothers, and teaches to eradicate slavery because it is far from the value of the purpose of life which is based on the values of God, Humanity, and Justice. ${ }^{18}$

\section{Closing}

The implementation of the provision of restitution, compensation and rehabilitation to victims of the crime of human trafficking as a form of legal protection cannot be applied because there is no clear mechanism or indicator regarding the mechanism for granting restitution and the calculation procedure used as a measuring tool used by law enforcement, namely judges in impose restitution sanctions that must be given to human trafficking. In addition, that victims and law enforcers find it difficult to prove or detail the total losses suffered by victims, so that law enforcers, especially judges, cannot determine the number of victims' losses in evidence in court. So it is necessary to regulate the amount of restitution for victims of the crime of human trafficking.

\section{References}

\section{Journals}

[1] Agus Takariawan and Sherly Ayuna Putri, Perlindungan Hukum terhadap Korban Human Trafficking dalam Perspektif Hak Asasi Manusia, Jurnal Hukum IUS QUIA IUSTUM NO. 2 VOL. 25 MEI 2018

[2] C.Kamea and Herlien, Penegakan Hukum Pidana Terhadap Kejahatan Perdagangan Orang Menurut Undang-Undang Nomor 21 Tahun 2007, Lex Crimen, V, No. 2, 2016

\footnotetext{
${ }^{15}$ M. Gargarin Friyandi and Aryani Witasari, Restorative Justice In Application For Crime Investigation Abuse In Polsek Middle Semarang, Jurnal Daulat Hukum Volume 2 Issue 1, March 2019, p. 41-44.

16Barda Nawawie Arief, Masalah Penegakan Hukum Dan Kebijakan Hukum Pidana Dalam Penanggulangan Kejahatan, Kencana Prenada Media, Jakarta, 2014, p. 55-64. See also: Barda Nawawie Arief, Bunga Rampai Kebijakan Hukum Pidana, Citra Aditya Bakti, 2005, p. 27-29.

${ }^{17}$ Sri Endah Wahyu Ningsih, Perbandingan Hukum Pidana Dari Perspektif Religious Law system, UNISSUlA Press, Semarang, 2012, p. 48.

${ }^{18} \mathrm{Human}$ trafficking has existed since the time of the Prophet, this is shown by the increasingly rampant slavery at that time. This made the Messenger of Allah take actions to eradicate slavery through various da'wah which made every human being at that time aware to stay away from slavery because it was against the teachings of Islam and human values. See: Karen Armstrong, Mohammad Prophet for Our Time, Mirza Media Utama, Bandung,2007, p. 267-268.
} 
[3] Ibnu Suka, Gunarto, and Umar Ma'ruf, Peran Dan Tanggung Jawab Polri Sebagai Penegak Hukum Dalam Melaksanaan Restorative Justice Untuk Keadilan Dan Kemanfaatan Masyarakat, Jurnal Hukum Khaira Ummah Vol. 13. No. 1 Maret 2018

[4] M.Gargarin Friyandi and Aryani Witasari, Restorative Justice In Application For Crime Investigation Abuse In Polsek Middle Semarang, Jurnal Daulat Hukum Volume 2 Issue 1, March 2019

[5] Ragil Tri Wibowo and Akhmad Khisni, Restorative Justice in Application for Crime Investigation on Property, Jurnal Daulat Hukum Volume 1 No. 2 June 2018

[6] Roswati Dewi, Sri Endah Wahyuningsih, and Umar Ma'ruf, Law Enforcement Of Giving Restitution For Victims Of Trafficking In The State Court Of Central Jakarta, Jurnal Daulat Hukum Volume 2 Issue 4, December 2019

[7] Sarwadi and Bambang Tri Bawono, Restorative Justice Approach in Diversion System for Settlement of Criminal Cases for Children in Indonesia, Jurnal Daulat Hukum Volume 3 Issue 4, December 2020

[8] Yenny AS, Anita Yuliastini, and Rini Setiawati, The Handling Of Human Trafficking With Mail Order Bride Mode In West Kalimantan, International Journal of Law Recontruction Volume 4, Number 2, September 2020

\section{Books}

[1] Barda Nawawie Arief, 2014, Masalah Penegakan Hukum Dan Kebijakan Hukum Pidana Dalam Penanggulangan Kejahatan, Kencana Prenada Media, Jakarta

[2] Barda Nawawie Arief, 2005, Bunga Rampai Kebijakan Hukum Pidana, Citra Aditya Bakti

[3] Karen Amstrong, 2007, Mohammad Prophet for Our Time, Mirza Media Utama, Bandung

[4] Mahrus Ali dan Syarif Nurhidayat, 2011, Penyelesaian Pelanggaran HAM Berat In Court System \& Out Court System, Gramata Publishing, Jakarta

[5] Romli Atmasasmita, 1992, Penulisan Karya Ilmiah Tentang Masalah Santunan Terhadap Korban Tindak Pidana, Badan Pembinaan Hukum Nasional, Departemen Kehakiman, Jakarta

[6] Soetandyo Wignjosoebroto, 2002, Hukum, Paradigma, Metode, dan Dinamika Masalahnya, HUMA, Jakarta

[7] Sri Endah Wahyu Ningsih, 2012, Perbandingan Hukum Pidana Dari Perspektif Religious Law system, UNISSUlA Press, Semarang

\section{Internet}

[1] Ahmad Sofyan, Pemberian Restitusi Kepadan Korban Tindak Pidana Dalam Sistem Peradilan Pidana Indonesia, Diakses Melalui business-law.binus.ac.id, on 12 May 2021

[2] Maria Advianti, KPAI: Pelaku Kekerasan Terhadap Anak Tiap Tahun Meningkat, Diakses Melalui www. KPAI.go.id, on 12 May 2021 